\title{
UPAYA MENINGKATKAN HASIL BELAJAR TEMATIK MATERI DAUR HIDUP HEWAN MELALUI MODEL SNOWBALL THROWING
}

\author{
Siti Mas'udah \\ MIN 1 Rembang \\ sitimasudah50@gmail.com \\ DOI : http://doi.org/10.37730/edutrained.v4i2.79 \\ Diterima: 15 Agustus 2020 | Disetujui: 26 November 2020 | Dipublikasikan: 29 November 2020
}

\begin{abstract}
Abstrak
Sudah seharusnya guru bertindak kreatif untuk membantu siswa memahami materi pelajaran. Salah satunya dengan menggunakan model Snwoball Throwig yang merupakan suatu model pembelajaran menyenangkan bagi siswa karena di dalamnya ada unsur permainan. Penulis menggunakan model ini pada siswa kelas IVC MIN 1 Rembang 2019 dengan tujuan ingin meningkatkan hasil belajar siswa dalam pembelajaran tematik materi daur hidup hewan pada kelas tersebut. Penulis menggunakan metode penelitian tindakan kelas dengan dua siklus untuk memperoleh data tentang kemampuan peserta didik. Data yang diperoleh menunjukkan bahwa model ini secara signifikan berhasil meningkatkan kemampuan peserta didik dalam pembelajaran tematik materi daur hidup hewan . Model Snwoball Throwing bisa menjadi salah satu model yang dapat membantu meningkatkan kemampuan peserta didik dalam materi daur hidup hewan.
\end{abstract}

Kata Kunci: hasil belajar,model Snowball Throwing, tematik.

\begin{abstract}
Teachers should act creatively to help students understand the subject matter. The Snwoball Throwig model is a fun learning model for students because it contains elements of play. The author uses this model in class IVC MIN 1 Rembang 2019 students with the aim of improving student learning outcomes in thematic learning material life cycle material for class IVC MIN 1 Rembang in 2019, the author uses the classroom action research method with two cycles to obtain data about the abilities of students. The data obtained showed that this model significantly succeeded in improving the students' abilities in thematic learning of animal life cycle materials. The Snwoball Throwing model can be a model that can help improve students' abilities in animal life cycle material
\end{abstract}

Keywords: learning outcomes, Snowball Throwing model, tematic 


\section{PENDAHULUAN}

Berdasarkan analisis hasil ulangan harian yang dilakukan peneliti diketahui bahwa hasil belajar siswa MIN 1 Rembang dalam pembelajaran Tematik Materi daur hidup hewan adalah rendah. Rendahnya hasil belajar siswa MIN1 Rembang kelas IV C dalam Pembelajaran Tematik Materi daur hidup hewan dipengaruhi oleh banyak faktor diantaranya adalah kurangnya pemberian motivasi terhadap siswa, model pembelajaran yang kurang tepat, kurangnya latihan dalam mengerjakan soal-soal, dan kurangnya penggunaan media. Pemberian motivasi telah dilakukan, beberapa model pembelajaran telah diterapkan, pemberian tugas di rumah juga telah diberikan, dan beberapa media juga sudah digunakan tetapi hasilnya belum menunjukkan seperti yang diinginkan.

Penulis memperkirakan yang dapat dilakukan untuk meningkatkan hasil belajar siswa MIN1 Rembang kelas IVC dalam pembelajaran tematik materi daur hidup hewan adalah penerapan model pembelajaran yang tepat, yakni model pembelajaran yang menyenangkan dan di dalamnya terdapat unsur permainan sehingga siswa tertarik dan termotivasi untuk mendalami materi yang ada sehingga hasil belajar siswa meningkat. Model yang diduga tepat yaitu model snowball throwing. Langkah-langkah model ini adalah: Apersepsi, pembagian kelompok, latihan terbimbing, permainan lempar bola, presentasi, dan evaluasi.

Berdasarkan kenyataan tersebut penulis mencoba mencari berbagai solusi untuk meningkatkan hasil belajar siswa MIN1 Rembang kelas IVC dalam pembelajaran tematik materi daur hidup hewan, dan dari berbagai penelitian yang telah dilakukan oleh banyak praktisi pendidikan tematik, ternyata ada berbagai cara yang mereka terapkan untuk membuat siswa mereka mendapatkan hasil belajar yang memuaskan.
Manfaat yang dapat diambil dari penelitian ini adalah: Bagi madrasah hasil penelitian ini diharapkan mampu menambah informasi tentang modelmodel pembelajaran, bagi guru penelitian ini dapat digunakan sebagai alternatif dalam pembelajaran tematik, bagi siswa penelitian ini dapat digunakan untuk membantu meningkatkan hasil belajar siswa pada pembelajaran tematik materi daur hidup hewan, dan bagi peneliti hasil penelitian ini dapat digunakan untuk mengetahui peningkatan hasil belajar siswa dengan menggunakan model snowball throwing. Solusi untuk meningkatkan motivasi belajar peserta didik MIN 1 Rembang kelas IVC pembelajaran Tematik Tema makananku sehat dan bergizi KD memahami siklus hidup beberapa jenis makhluk hidup yang ada di lingkungan sekitar dan upaya pelestariannya sehingga hasil belajar peserta didik MIN 1 Rembang kelas IVC pembelajaran Tematik Tema makananku sehat dan bergizi KD memahami siklus hidup beberapa jenis makhluk hidup yang ada di lingkungan sekitar dan upaya pelestariannya akan meningkat. Motivasi peserta didik ysng rendah ternyata mempengaruhi hasil belajar peserta didik MIN 1 Rembang kelas IVC. Pembelajaran Tematik Tema makananku sehat dan bergizi KD memahami siklus hidup beberapa jenis makhluk hidup yang ada di lingkungan sekitar dan upaya pelestariannya dapat ditingkatkan dengan menggunakan model pembelajaran yang tepat. Salah satu model tersebut adalah Snowball Throwing. Model pembelajaran Snowball Throwing merupakan salah satu model pembelajaran yang dikembangkan berdasarkan pendekatan kontekstual (CTL). Snowball Throwing yang menurut asal katanya berarti 'bola salju bergulir' dapat diartikan sebagai model pembelajaran dengan menggunakan bola pertanyaan dari kertas yang digulung bulat berbentuk bola kemudian dilemparkan secara bergiliran di antara sesama anggota kelompok. Dilihat dari pendekatan yang digunakan dalam pembelajaran bahasa, model 
pembelajaran Snowball Throwing ini memadukan pendekatan komunikatif, integratif, dan keterampilan proses. Kegiatan melempar bola pertanyan ini akan membuat kelompok menjadi dinamis, karena kegiatan siswa tidak hanya berpikir, menulis, bertanya, atau berbicara, akan tetapi mereka juga melakukan aktivitas fisik yaitu menggulung kertas dan melemparkannya pada siswa lain. Dengan demikian, tiap anggota kelompok akan mempersiapkan diri karena pada gilirannya mereka harus menjawab pertanyaan dari temannya yang terdapat dalam bola kertas.

\section{KAJIAN PUSTAKA}

\section{Pengertian Hasil Belajar}

Menurut Hamalik (2015:62) hasil belajar adalah pola-pola perbuatan, nilainilai, pengertian-pengertian dan sikapsikap, serta kemampuan siswa.

Menurut Juliah ( 2013: 14) hasil belajar adalah segala sesuatu yang menjadikan siswa sebagai akibat dari kegiatan belajar yang dilakukannya.

Dimyati dan Mujiono ( 2009:20) berpendapat bahwa hasil belajar merupakan puncak proses belajar, hasil belajar tersebut terjadi terutama berkat evaluasi guru. Hasil belajar dapat berupa dampak pengajaran dan dampak pengiring. Kedua manfaat tersebut bermanfaat bagi guru dan siswa.

Benjamin S. Bloom (Dimyati dan Mudjiono, 2006: 26-27) menyebutkan enam jenis perilaku ranah kognitif, sebagai berikut: a. Pengetahuan, mencapai kemampuan ingatan tentang hal yang telah dipelajari dan tersimpan dalam ingatan. Pengetahuan itu berkenaan dengan fakta, peristiwa, pengertian kaidah, teori, prinsip, atau metode. b. Pemahaman, mencakup kemampuan menangkap arti dan makna tentang hal yang dipelajari. c. Penerapan, mencakup kemampuan menerapkan metode dan kaidah untuk menghadapi masalah yang nyata dan baru. Misalnya, menggunakan prinsip. d. Analisis, mencakup kemampuan merinci suatu kesatuan ke dalam bagian-bagian sehingga struktur keseluruhan dapat dipahami dengan baik. Misalnya mengurangi masalah menjadi bagian yang telah kecil. e. Sintesis, mencakup kemampuan membentuk suatu pola baru. Misalnya kemampuan menyusun suatu program. 13 f. Evaluasi, mencakup kemampuan membentuk pendapat tentang beberapa hal berdasarkan kriteria tertentu. misalnya, kemampuan menilai hasil ulangan.

Berdasarkan beberapa pendapat tersebut di atas, dapat ditarik simpulan bahwa hasil belajar adalah segala sesuatu yang diakibatkan karena dampak dari pembelajaran.

Faktor yang mempengaruhi hasil belajar.

Menurut Munadi dalam Rusman. T (2013:124) faktor-faktor yang mempengaruhi hasil belajar antara lain: Faktor internal dan faktor ekternal dimana faktor internal adalah faktor yang ada dalam diri individu yang sedang belajar, faktor internal meliputi:faktor jasmaniah dan faktor psikologis. Faktor internal meliputi faktor fisiologis dan faktor psikologis, sedangkan faktor eksternal adalah faktor yang ada di luar individu. Faktor eksternal meliputi: faktor keluarga, faktor sekolah, dan faktor masyarakat.

Menurut Sudjana hasil belajar adalah perubahan kemampuan yang dimiliki peserta didik setelah mengalami proses belajar. Penguasaan peserta didik antara lain berupa penguasaan kognitif yang dapat diketahui melalui hasil belajar. Usaha untuk mencapai aspek tersebut dipengaruhi oleh faktor-faktor yang mempengaruhi hasil belajar.2 Faktorfaktor yang mempengaruhi hasil belajar antara lain : 1) Faktor Ekternal a) Lingkungan yaitu suatu kondisi yang ada disekitar peserta didik contoh suhu, udara, cuaca, juga termasuk keadaan sosial yang ada disekitar peserta didik, b) Faktor Instrumental yaitu faktor yang 
adanya dan penggunaannya dirancang sesuai dengan hasil yang diharapkan. Contoh : kurikulum, metode, sarana, media, dan sebagainya. 2) Faktor Internal Yaitu faktor Internal yang mempengaruhi peserta didik antara lain : Kondisi psikologi dan fisiologi peserta didik. Faktor-faktor yang mempengaruhi proses dan hasil belajar siswa secara garis besar terbagi dua bagian, yaitu faktor internal dan eksternal. 1) Faktor internal siswa a) Faktor fisiologis siswa, seperti kondisi kesehatan dan kebugaran fisik, serta kondisi panca inderanya terutama penglihatan dan pendengaran. b) Faktor psikologis siswa, seperti minat, bakat, intelegensi, motivasi, dan kemampuankemampuan kognitif seperti kemampuan persepsi, ingatan, berpikir dan kemampuan dasar pengetahuan yang dimiliki. 2) Faktor-faktor eksternal siswa a) Faktor lingkungan siswa Faktor ini terbagi dua, yaitu pertama, faktor lingkungan alam atau non sosial seperti keadaan suhu, kelembaban udara, waktu (pagi, siang, sore, malam), letak madrasah, dan sebagainya. Kedua, faktor lingkungan sosial seperti manusia dan budayanya. b) Faktor instrumental yang termasuk faktor instrumental antara lain gedung atau sarana fisik kelas, sarana atau alat pembelajaran, media pembelajaran, guru, dan kurikulum atau materi pelajaran serta strategi pembelajaran. Tinggi rendahnya hasil belajar peserta didik dipengaruhi banyak faktor-faktor yang ada, baik yang bersifat internal maupun eksternal. Faktor-faktor tersebut sangat mempengaruhi upaya pencapaian hasil belajar siswa dan dapat mendukung terselenggaranya kegiatan proses pembelajaran, sehingga dapat tercapai tujuan pembelajaran

\section{Manfaat hasil belajar}

Menurut Nana Sudjana dan Ibrohim (2009: 3 ), hasil belajar pada hakekatnya adalah perubahan tingkah laku seseorang yang mencakup kemampuan kognitif, afektif, dan psikomotorik setelah mengikuti suatu proses belajar mengajar tertentu. Pendidikan dan pengajaran dikatakan berhasil apabila perubahan- perubahan yang tampak pada siswa merupakan akibat dari proses belajar mengajar yang dialaminya yaitu proses yang ditempuhnya melalui program dan kegiatan yang dirancang dan dilaksanakan oleh guru dalam proses pengajarannya. Berdasarkan hasil belajar siswa, dapat diketahui kemampuan dan perkembangan sekaligus tingkat keberhasilan pendidikan. Hasil belajar harus menunjukkan perubahan keadaan menjadi lebih baik, sehingga bermanfaat untuk: (a) menambah pengetahuan, (b) lebih memahami sesuatu yang belum dipahami sebelumnya, (c) lebih mengembangkan keterampilannya, (d) memiliki pandangan yang baru atas sesuatu hal, dan (e) lebih menghargai sesuatu daripada sebelumnya. Dapat disimpulkan bahwa istilah hasil belajar merupakan perubahan dari siswa sehingga terdapat perubahan dari segi pegetahuan, sikap, dan keterampilan.

\section{Pembelajaran Tematik}

Hakekat pembelajaran tematik pada dasarnya pembelajaran tematik merupakan terapan pembelajaran terpadu. Pembelajaran tematik yang diharapkan berkembang di sekolah dasar mengarah pada penggabungan dari webbed model (model jaring laba-laba) dan integrated model (model terpadu). Istilah pembelajaran tematik pada dasarnya adalah model pembelajaran terpadu yang menggunakan tema untuk mengaitkan beberapa mata pelajaran sehingga dapat memberikan pengalaman bermakna pada siswa (Depdiknas dalam Trianto, 2011)

Menurut BPSDMPK (2012: 11), pembelajaran tematik merupakan suatu pendekatan dalam pembelajaran yang mengaitkan atau memadukan beberapa kompetensi dasar/indikator dari standar kompetensi beberapa mata pelajaran menjadi satu kesatuan dikemas dalam satu tema.

Sementara itu Trianto (2011: 152) menyatakan bahwa pembelajaran tematik menawarkan model-model 
pembelajaran yang menjadikan aktivitas pembelajaran itu relevan dan penuh makna bagi siswa dengan memberdayakan pengetahuan dan pengalaman siswa untuk membantu memahami dunia nyatanya. Perolehan keutuhan belajar, pengetahuan dan kebulatan pandangan tentang kehidupan dan dunia nyata hanya dapat direfleksikan melalui pembelajaran terpadu (Willian dalam Tianto, 2011). Selanjutnya Majid (2014: 87) menyatakan bahwa pembelajaran tematik menggabungkan suatu konsep dalam beberapa bidang studi yang berbeda dengan harapan anak akan belajar lebih baik dan bermakna.

Berdasarkan beberapa pendapat tersebut di atas, dapat ditarik simpulan bahwa pendekatan pembelajaran tematik adalah suatu pendekatan pembelajaran, yang mengangkat suatu tema tertentu untuk mengikat beberapa materi pelajaran. Tema yang dipilih harus berkaitan erat dengan pengalaman nyata siswa dalam kehidupan sehari-hari, sehingga pembelajaran yang dialami siswa dapat memberikan pengalaman bermakna bagi diri siswa sendiri.

Tujuan Pembelajaran Tematik dalam pembelajaran diantaranya: memberikan pengetahuan dan wawasan tentang pembelajaran tematik, memberikan pemahaman kepada Peneliti tentang pembelajaran tematik yang sesuai dengan perkembangan peserta didik kelas awal Sekolah Dasar, memberikan keterampilan kepada Peneliti dalam menyusun perencanaan, melaksanakan, dan melakukan penilaian dalam pembelajaran tematik, memberikan wawasan, pengetahuan dan pemahaman bagi pihak terkait, sehingga diharapkan dapat memberikan dukungan terhadap kelancaran pelaksanaan pembelajaran.

Fungsi Pembelajaran Tematik Yaitu: dengan menggabungkan beberapa kompetensi dasar dan indikator serta isi mata pelajaran akan terjadi penghematan, karena tumpang tindih materi dapat dikurangi bahkan dihilangkan, peserta didik mampu melihat hubungan-hubungan yang bermakna, sebab isi/materi, pembelajaran lebih berperan sebagai sarana atau alat, bukan tujuan akhir, pembelajaran menjadi utuh sehingga peserta didik akan mendapat pengertian mengenai proses dan materi yang tidak terpecah-pecah, dengan adanya pemanduan antar matapelajaran maka penguasaan konsep akan semakin baik dan meningkat.

\begin{tabular}{lr}
\multicolumn{2}{r}{ Sedangkan Pembelajaran Tematik di } \\
SD & memiliki \\
karakteristik khusus & beberapa \\
yang
\end{tabular}
membedakannya dengan pendekatan pembelajaran lain. Beberapa ahli telah merumuskan beberapa karakteristik pendekatan pembelajaran tematik yang menunjukkan perbedaan tersebut. Menurut Tim Puskur (2006) (dalam BPSDMPK, 2012: 9), pendekatan pembelajaran tematik memiliki karakteristik sebagai berikut: Pembelajaran berpusat pada peserta didik.

Pembelajaran tematik dikatakan sebagai pembelajaran yang berpusat pada peserta didik, karena pada dasarnya pembelajaran tematik merupakan suatu pendekatan pembelajaran yang memberikan keleluasaan pada peserta didik, baik secara individu maupun kelompok. Peserta didik diharapkan dapat aktif mencari, menggali, dan menemukan konsep serta prinsip-prinsip dari suatu pengetahuan yang harus dikuasainya sesuai dengan perkembangannya, dan memberikan pengalaman langsung kepada anak.

Pembelajaran tematik diprogramkan untuk melibatkan peserta didik secara langsung dalam pembelajaran yang mengaitkan antar konsep dan prinsip yang dipelajari dari beberapa pembelajaran. Sehingga peserta didik akan memahami hasil belajarnya sesuai 
dengan fakta dan peristiwa yang dialami, bukan sekedar informasi dari Penelitinya. Peneliti lebih banyak bertindak sebagai fasilitator dan katalisator yang membimbing kearah tujuan pembelajaran yang ingin dicapai. Sedangkan peserta didik sebagai aktor pencari fakta dan informasi untuk mengembangkan pengetahuannya, pemisahan pembelajaran tidak kelihatan atau antar pembelajaran menyatu.

Pembelajaran tematik memusatkan perhatian pada pengamatan dan pengkajian suatu gejala atau peristiwa dari beberapa pembelajaran sekaligus, tidak dari sudut pandang yang terkotakkotak. Sehingga memungkinkan peserta didik untuk memahami suatu fenomena pembelajaran dari segala sisi yang utuh, menyajikan konsep dari berbagai pembelajaran dalam suatu proses pembelajaran sehingga bermakna.

Pembelajaran tematik mengkaji suatu fenomena dari berbagai macam aspek yang akan membentuk semacam jalin anantar pengetahuan yang dimiliki peserta didik, sehingga berdampak kebermaknaan dari materi yang dipelajari. Hasilnya tak akan didapat dari segala konsep yang diperoleh dan keterkaitannya dengan konsep-konsep lain yang dipelajari. Hal ini diharapkan akan berdampak pada kemampuan peserta didik untuk memecahkan masalah-masalah yang nyata dalam kehidupannya, bersifat fleksibel.

Pembelajaran tematik bersifat luwes (fleksibel) dimana Peneliti dapat mengaitkan bahan ajar dari satu mata pelajaran dengan mata pelajaran lainnya, bahkan mengaitkannya dengan kehidupan peserta didik dan keadaan lingkungan dimana sekolah dan peserta didik berada. Teknik penilaian dapat dilakukan dengan tes maupun non tes meliputi observasi, unjuk kerja dan penilaian produkf. Hasil pembelajaran dapat berkembang sesuai minat dan kebutuhan anak. Pada pembelajaran tematik dikembangkan pendekatan PAKEM (pembelajaran yang aktif kreatif efektif dan menyenangkan) yang melibatkan peserta didik secara aktif dalam proses pembelajaran dengan melihat bakat, minat, dan kemampuan peserta didik sehingga memungkinkan anak termotivasi untuk belajar terus menerus.

Depdikbud 1996 (dalam Trianto, 2011: 165) mengemukakan bahwa karakteristik pembelajaran terpadu sebagai suatu proses pembelajaran yaitu: Holistic, suatu jejala atau fenomena yang menjadi pusat perhatian dalam pembelajaran yang dikaji dari beberapa bidang kajian tidak dari sudut pandang yang terkotak-kotak, bermakna, rujukan yang nyata dari segala konsep yang diperoleh dan keterkaitannya dengan konsep lain akan menambah kebermaknaan konsep yang dipelajari, eutentik, peserta didik memahami langsung prinsip dan konsep yang ingin dipelajarinya, aktif, menekankan keaktifan peserta didik dalam pembelajaran.

Lebih lanjut Majid (2014: 89) menyatakan bahwa pembelajaran tematik memiliki karakteristik sebagai berikut: Berpusat pada peserta didik, menempatkan peserta didik sebagai subyek belajar dan Peneliti sebagai fasilitator, memberikan pengalaman langsung, peserta didik dihadapkan pada sesuatu yang nyata sebagai dasar untuk memahami hal-hal yang abstrak, pemisahan mata pelajaran tidak begitu jelas, fokus pembahasan diarahkan kepada pembahasan tema-tema yang paling dekat berkaitan dengan kehidupan peserta didik, menyajikan konsep dari berbagai mata pelajaran, bersifat fleksibel, dapat mengaitkan bahan ajar dengan berbagai mata pelajaran, kehidupan peserta didik dan keadaan lingkungan dimana sekolah dan peserta didik berada, menggunakan prinsip belajar sambil bermain dan menyenangkan. 
Selanjutnya Rusman (2015: 146) memaparkan tentang karakteristik pembelajaran tematik sebagai berikut: Berpusat pada peserta didik, memberikan pengalaman langsung pada anak, pemisahan mata pelajaran tidak begitu jelas, menyajikan konsep dari berbagai mata pelajaran, bersifat luwes / fleksibel, hasil pembelajaran berkembang sesuai dengan minat, bakat dan kebutuhannya, menggunakan prinsip bermain sambil belajar

Beberapa pendapat di atas
tentang karakteristik
$\begin{aligned} & \text { pembelajaran } \\ & \text { tematik menggambarkan }\end{aligned}$
$\begin{aligned} & \text { bahwa } \\ & \text { pendekatan }\end{aligned}$
tematik memuat lima kata kunci yaitu
menyeluruh, pembelajaran sesuai dengan
kenyataan, belajar bermakna,
memberikan kesempatan kepada peserta
$\begin{aligned} & \text { didik terlibat aktif dalam proses } \\ & \text { pembelajaran, dan efektif dalam } \\ & \text { penggunaan waktu. }\end{aligned}$

\section{Model Snowball Throwing}

Jhon. M.Echol dan Hasan Shadily menyebutkan bahwa, kata "snow" berarti salju, "ball" berarti bola sedangkan "throw" berarti melempar. Jadi snowball throwing yaitu melempar bola salju. Slamet Widodo memaparkan bahwa metode snowball throwing merupakan salah satu modifikasi teknik bertanya yang menitik beratkan pada kemampuan membuat pertanyaan yang dikemas dalam permainan menarik yaitu saling melempar bola salju yang berisikan pertanyaan. Arta Januardana, dkk memaparkan bahwa metode snowball throwing adalah cara belajar melalui permainan yaitu saling lempar bola kertas yang berisi pertanyaan, mengajak siswa untuk selalu siap dan tanggap menerima pesan dari orang lain serta lebih responsif dalam menghadapi segala tantangan khususnya dalam pembelajaran.4 Diantara permaianan metode snowball throwing secara kooperatif dan aktif sangat berbeda pelaksanaannya, apabila dilihat dari pengertian secara pembelajaran kooperatif memiliki pengertian yaitu salah satu modifikasi dari teknik bertanya yang menitikberatkan pada kemampuan merumuskan pertanyaan yang dikemas dalam sebuah permainan yang menarik yaitu saling melempar bola salju yang berisi pertanyaan. Dilihat dari model pembelajaran yang digunakan, metode ini akan membuat kelompok menjadi dinamis, karena kegiatan siswa tidak hanya berfikir, menulis atau berbicara. Akan tetapi mereka juga melakukan aktifitas fisik yaitu menggulung dan melempar kertas yang dibentuk bola salju kepada temannya. Dengan demikian setiap anggota kelompok akan mempersiapkan diri karena pada gilirannya mereka harus menjawab pertanyaan dari temannya yang terdapat di dalam bola kertas. Dari uraian diatas bahwa metode snowball throwing adalah pembelajaran yang mengedepankan partisipasi aktif peserta didik secara berkelompok guna mencapai tujuan bersama, dilakukan menggunakan bahan kertas berisi pertanyaan yang dibentuk seperti bola kemudian dilemparkan secara bergiliran ke peserta didik yang lain untuk dijawab. Metode ini dapat melatih kesiapan siswa, membantu memahami konsep materi sulit, menciptakan suasana yang menyenangkan, membangkitkan motivasi belajar, menumbuhkan kerjasama, berpikir kritis dan menciptakan proses pembelajaran aktif. Langkah-langkah metode Snowball Throwing 1) Guru menyampaikan materi pembelajaran yang akan disampaikan. 2) Guru membentuk kelas menjadi beberapa kelompok, kemudian guru memanggil perwakilan ketua kelompok untuk mendengarkan intruksi dari guru. Setelah dirasa faham guru meminta perwakilan ketua kelompok kembali ke tempat kelompok masing-masing. 3) Kemudian perwakilan kelompok tadi diberi beberapa lembar kertas oleh guru dan kemudian dibagikan ke masing-masing peserta didik dalam kelompok tersebut. 4) Setelah itu peserta didik diminta untuk menuliskan soal dari materi yang sudah di jelaskan oleh guru dalam lembaran 
tersebut. 5) Setelah selesai menuliskan soal, ketua kelompok meminta kembali lembaran-lembaran tersebut kemudian akan dijadikan satu dengan kelompok lain dan di bentuk seperti gulungan kertas yang akan menjadi bola salju dalam pembelajaran tersebut. 6) Setelah semua lembaran terkumpul menjadi satu barulah guru mulai melempar kertas tersebut kepada masing-masing kelompok dengan diselingi nyanyian untuk memutarkan bola salju tersebut, sampai nyanyian selesai dan bola salju jatuh pada kelompok tersebut maka kelompok tersebut yang harus menjawab soal dari gilingaan bola yang berisikan kertas tersebut. 7) Salah satu kelompok mempresentasikan jawaban dari lembaran tersebut. 8) Setelah semua sudah mendapat lemparan bola salju barulah guru dan peserta didik menyimpulkan bersama-sama. 9) Evaluasi. 10) Penutup, Karakteristik metode Snowball Throwing. Metode snowball throwing melatih peserta didik untuk lebih tanggap menerima pesan dari orang lain, dan menyampaikan pesan tersebut kepada temannya dalam satu kelompok. Karakteristik metode Snowball Throwing diantaranya sebagai berikut: 1) Peserta didik dalam kelompok kooperatif yang bertujuan untuk menguasai materi. 2) Peserta didik diberikan beberapa pertanyaan untuk melatih pemahaman peserta didik seputar materi. 3) Penilaian yang diberikan dalam pembelajaran kooperatif didasarkan pada hasil kerja kelompok. Namun demikian, guru perlu menyadari bahwa sebenarnya prestasi yang diharapkan adalah prestasi setiap individu peserta didik, 4) Peserta didik belajar bekerjasama, peserta didik juga harus belajar bagaimana membangun rasa percaya diri.6 d. Prinsip-prinsip metode Snowball Throwing terdapat beberapa prinsip yang harus diketahui dalam menerapkan metode pembelajaran snowball throwing. Prinsip-prinsip tersebut yaitu sebagai berikut: 1) Metode ini menuntut peserta didik untuk belajar secara aktif atau dinamakan dengan student active learning. 2) Metode ini menuntut peserta didik untuk belajar bekerjasama dengan kelompok atau dinamakan dengan cooperative learning. 3) Metode ini menuntut guru untuk menerapkan kegiatan pembelajaran yang bersifat partisipatorik. 4) Pembelajaran bersifat menyenangkan atau dinamakan dengan joyfull learning.7 e. Kelebihan dan kekurangan metode Snowball Throwing. Kelebihan metode Snowball Throwing 1) Metode Snowball Throwing ini mampu meningkatkan rasa percaya diri pada peserta didik untuk menyampaikan pendapat ataupun hasil diskusi di depan teman-temannya. 2) Peserta didik bertanggung jawab untuk menjawab pertanyaan yang telah diperoleh dari peserta didik yang lain melalui bola salju yang berisikan soal tersebut. 3) Pembelaran lebih efektif dan efisien. 4) Pembelajaran antara peserta didik dan guru lebih menyenangkan karena peserta didik dapat bermain bola kertas kepada teman lainnya. 5) Membuat peserta didik siap dengan berbagai kemungkinan karena peserta didik tidak tahu soal apa yang akan didapat yang telah dibuat oleh temannya. 6) Ketiga aspek baik kognitif, afektif dan psikomotorik dapat tercapai. Kelemahan Snowball Throwing 1) Situasi pembelajaran menjadi lebih gaduh, karena kurang kondusif dalam pengaturan kelas. 2) Peserta didik yang tidak mampu mengandalkan kemampuan yang dimiliki oleh diri sendiri. 3) Materi yang diberikan guru tidak meluas. 4) Waktu yang dibutuhkan dalam menerapkan metode ini cukup lama. Berikut penulis sampaikan beberapa contoh penerapan model snowball throwing.

\section{Tahap 1: Apersepsi}

Menetapkan isi pembelajaran, meninjau ulang pembelajaran sebelumnya, menetapkan tujuan pembelajaran, menetapkan dan menjelaskan langkahlangkah pembelajaran.

\section{Tahap 2: Pembagian Kelompok}

Peneliti membagi peserta didik menjadi 4 kelompok, peneliti menunjuk satu 
peserta didik untuk menjadi ketua kelompok

\section{Tahap 3: Latihan Terbimbing}

Peneliti memanggil ketua kelompok untuk menerima materi yang akan dipelajari, ketua kelompok kembali ke kelompoknya lalu menyampaikan materi kepada teman satu kelompok, setelah mendapat materi dari ketua kelompok, anggota kelompok menulis pertanyaan pada selembar kertas, setelah kartas diisi dengan pertanyaan, peserta didik membentuk kertas tersebut seperti bola salju

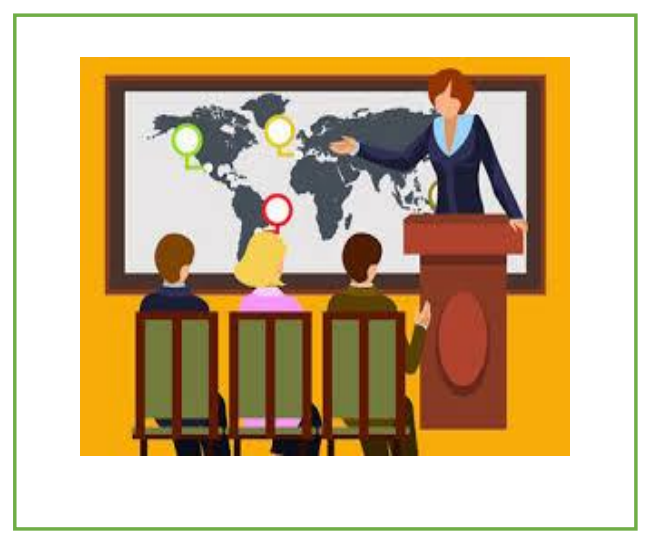

Tahap 4 : permainan melempar bola

Peserta didik melempar bola kertas ke segala arah, setelah melempar bola peserta didik akan mengambil bola yang telah dilempar dari peserta didik yang lainsecara acak, peserta didik akan menjawab pertanyaan yang ada dalam bola salju, peserta didik akan kembali melempar bola salju yang telah ditulis jawabanya, peserta didik kembali mengambil bola salju yang telah dilempar , peserta didik kembali menjawab dengan jawaban alternatif dari jawaban yang pertama dan ditulis dibawah jawaban yang pertama, peserta didik mengumpulkan bola salju pada ketua kelompok

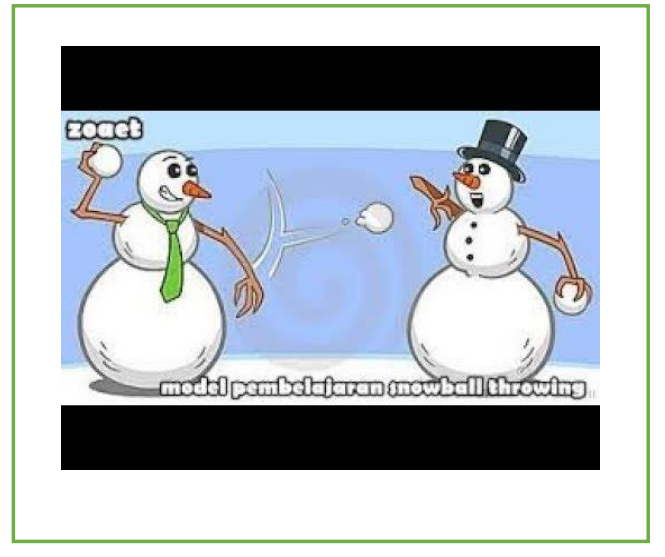

\section{Tahap 5 : presentasi}

Ketua kelompok mempresentasikan hasil jawaban teman satu kelompoknya

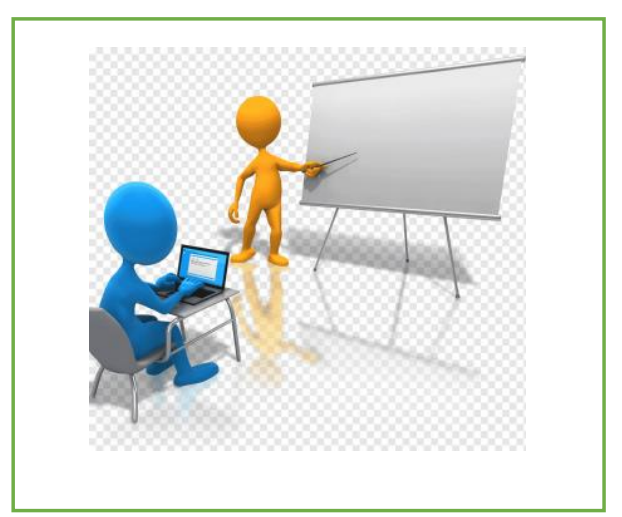

\section{Tahap 6 : Evaluasi}

Peneliti mengevaluasi jawaban dari peserta didik dan memberi penguatan Peneliti membuat kesimpulan

\section{METODE PENELITIAN}

Penelitian ini menggunakan jenis Penelitian Tindakan Kelas (PTK). PTK dilaksanakan dalam bentuk proses pengkajian berdaur 4 tahap, yaitu: 1. Perencanaan tindakan (PLAN). Pada tahap ini peneliti melakukan kegiatan-kegiatan berikut ini: Menetapkan KD yang (sesuai waktu/kalender akademik), menetapkan indikator pencapaian, menetapkan masalah yang akan ditingkatkan, yakni "motivasi dan hasil belajar", menetapkan model pembelajaran yang akan digunakan, yaitu model Snowball Throwing, menyusun rencana pembelajaran dengan menggunakan 
model Snowball Throwing untuk tiga kali pertemuan, membuat instrumen untuk memperoleh data, yakni dengan menggunakan tes dan teknik penilaian lainnya sesuai indikator yang akan dicapai, dan menetapkan rekan sebagai observer/kolaborator untuk membantu melakukan observasi selama proses pembelajaran.

2. Pelaksanaan tindakan (ACTION). Pada tahap ini, peneliti melaksanakan kegiatan yang telah direncanakan di perencanaan tindakan terutama proses pembelajaran dengan berpedoman pada Rencana Pelaksanaan Pembelajaran (RPP) yang telah dibuat.

\section{Pengamatan (OBSERVE)}

Pada tahap ini, ketika peneliti melaksanakan kegiatan pembelajaran, peneliti dan dibantu oleh beberapa teman sejawat (observer/kolaborator) untuk melakukan kegiatan pengamatan. Adapun yang dijadikan objek pengamatan adalah proses pelaksanaan pembelajaran, dan perilaku peserta didik selama mengikuti proses pembelajaran.

4. Diskusi refleksi

Setelah peneliti dan teman sejawat telah memperoleh data berupa pelaksanaan pembelajaran di kelas, perilaku peserta didik selama mengikuti pembelajaran dan hasil evaluasi untuk mengetahui kompetensi akademik peserta didik, maka peneliti dan teman sejawat melakukan diskusi refleksi. Kegiatan ini dimaksudkan untuk mengetahui kelemahan-kelemahan dalam pelaksanaan pembelajaran dan memberikan solusi untuk perbaikan pada siklus berikutnya. Subjek penelitian ini adalah siswa kelas IVC MIN 1 Rembang. Jumlah keseluruhan siswa di kelas IV C adalah 22 siswa. Rinciannya, siswa perempuan ada 11 , siswa laki-laki ada 11 . Hasil belajar mereka pada pembelajaran Tematik, dilihat dari analisis nilai ulangan setelah menyelesaikan 1 bulan pembelajaran (1 KD) rata-rata nilai mereka rendah.

Penelitian Tindakan Kelas ini menggunakan observasi dan tes. Dimana observasi ini digunakan untuk memperoleh data tentang proses pelaksanaan tindakan (PBM) yang menggunakan model Snowball Throwing. Pelaksanaan observasi ini, peneliti dibantu oleh tiga (3) teman sejawat dengan maksud agar proses pembelajaran bias direkam sedetail mungkin dari aspek langkah-langkah pembelajaran, perilaku guru dan peserta didik. Untuk melakukan observasi peneliti menggunakan lembar observasi untuk mengetahui kegiatan guru dan lembar observasi untuk mengetahui kegiatan peserta didik. Sedangkan Tes digunakan untuk memperoleh data hasil belajar peserta didik. Tes yang digunakan adalah berupa tes tulis dengan soal-soal Essay.Tes diberikan setelah selesai setiap kali pertemuan (untuk setiap siklus). Berikut ini adalah langkah langkah dalam menerapkan model Snowball Throwing. Pertama-tama guru menerangkan aturan main model Snowball Throwing kemudian guru menyampaikan materi yang akan dipelajari. Setelah siswa memahami penggunaan model Snowball Throwing maka guru memberikan latihan beberapa soal tentang daur hidup hewan yang harus diselesaikan siswa dengan menggunakan model Snowball Throwing. Tehnik penggunaan model Snowball Throwing adalah (1) Peneliti membagi siswa menjadi 4 kelompok dan menunjuk satu siswa menjadi ketua pada setiap kelompok. (2) Peneliti memberi materi pada ketua kelompok dan ketua kelompok menyampaikan materi kepada teman kelompoknya. (3) Ketua kelompok memberi intruksi pada kelompoknya untuk membuat soal yang ditulis mencapai kertas yang kemudian kertas itu diremas sehingga menjadi seperti bola salju. (4) setiap siswa melempar kertas yang berbentuk seperti bola salju ke arah teman secara bebas. (5) siswa segera menulis jawaban pada kertas soal yang ia terima dari lemparan teman dan melemparnya kembali ke teman yang lain. (6) siswa memberi jawaban alternatif pada kertas soal yang telah terjawab.(7) Ketua kelompok mempresentasikan dan yang lain menanggapinya. 


\section{HASIL PENELITIAN DAN PEMBAHASAN}

\section{Hasil Penelitian}

Hasil penelitian tindakan kelas pada siswa kelas IV C MIN Rembang tentang pemanfaatan model Snowball Throwing untuk menyelesaikan pembelajaran tematik materi daur hidup hewan mulai dari hasil pra siklus, siklus I dan siklus II disajikan dalam bentuk tabel.

Tabel 1.

Hasil belajar siswa pra siklus

\begin{tabular}{ccc}
\hline No & Hasil belajar & Pre Tes \\
\hline 1 & Nilai tertinggi & 70 \\
\hline 2 & Nilai terendah & 40 \\
\hline 3 & Nilai rata2 & 57,27 \\
\hline
\end{tabular}

Hasil belajar sebelum dilakukannya tindakan pada materi Daur hidup hewan yang dilakukan di kelas IVC MIN 1 Rembang menunjukkan bahwa nilai tertinggi siswa adalah 70 dan nilai terendah adalah 40 dengan rata-rata niai 57,27 .

Data tersebut menunjukkan bahwa hasil belajar siswa kelas IVC MIN 1 Rembang masih rendah karena hampir semua siswa kelas IVC tidak mencapai kriteria ketuntasan minimal (KKM) kelas tersebut yaitu 70. Model yang digunakan oleh guru sebelum diadakan tindakan adalah dengan menggunakan model ceramah, sehingga siswa tidak tertarik dan termotivasi dengan materi yang diberikan, sehingga hasil belajar siswa meningkat. Berdasarkan kenyataan tersebut maka diperlukan sebuah tindakan yang bisa membantu memotivasi dan menarik siswa dalam mempelajari sebuah materi. Peneliti menggunakan model Snowball Throwing pada siklus I.
Tabel 2.

Perbandingan hasil belajar pra siklus dan siklus 1

\begin{tabular}{cccc}
\hline No & Hasil Belajar & $\begin{array}{c}\text { Pra } \\
\text { siklus }\end{array}$ & $\begin{array}{c}\text { Siklus } \\
1\end{array}$ \\
\hline 1 & $\begin{array}{c}\text { Nilai } \\
\text { tertinggi }\end{array}$ & 70 & 80 \\
\hline 2 & $\begin{array}{c}\text { Nilai } \\
\text { terendah }\end{array}$ & 40 & 50 \\
\hline 3 & Rata2 & 57,27 & 69,09 \\
\hline
\end{tabular}

Peningkatan hasil belajar dilihat dari nilai yang didapat siswa sebelum dan sesudah pembelajaran menggunakan model Snowball Throwing nilai tertinggi meningkat di siklus I yang awalnya 70 menjadi 80, peningkatan juga terjadi pada nilai rata-rata. Nilai rata-rata yang awalnya 57,27 meningkat menjadi 69,09. Nilai terendah pada siklus I juga naik dari nilai terendah pada pra siklus yaitu dari 40 meningkat menjadi 50. Pembelajaran pada siklus I menggunakan model ceramah dengan model Snowball Throwing terbukti berpengaruh terhadap peningkatan hasil belajar siswa dibandingkan dengan hasil belajar pra siklus. Setelah dilakukan refleksi pada siklus 1 kekurangan siklus I dapat diperbaiki pada siklus II. Pada siklus II ini guru menggunakan model Snowball Throwing tetapi dengan penyempurnaan. Misalkan cara memberikan instruksi lebih jelas dan mengelola pembelajaran lebih semangat dan menyenangkan. Setelah pembelajaran berakhir dan diadakan evaluasi hasil pembelajaran maka diperoleh data hasil belajar siswa pada siklus II.

Tabel 3.

Perbandingan Hasil Belajar pada Siklus I dan Siklus II

\begin{tabular}{llll}
\hline No & $\begin{array}{l}\text { Nilai hasil } \\
\text { belajar }\end{array}$ & $\begin{array}{l}\text { Siklus } \\
\text { I }\end{array}$ & $\begin{array}{l}\text { Siklus } \\
\text { II }\end{array}$ \\
\hline Nilai tertinggi & 80 & 100 \\
\hline Nilai terendah & 50 & 60 \\
\hline Rata2 & 69,09 & 80,45
\end{tabular}

Berdasarkan uraian data tersebut menunjukkan bahwa nilai tertinggi, nilai terendah dan nilai rata-rata hasil belajar siswa kelas IVC MIN 1 Rembang pada 
siklus II meningkat, nilai tertinggi yang pada siklus I 80 meningkat menjadi 100, nilai terendah yang pada siklus I 50 meningkat 10 menjadi 60 , nilai rata-rata yang pada siklus I 69,09 meningkat menjadi 80,45. Pada siklus II ada 2 siswa yang nilainya tidak tuntas KKM yaitu 60 . Siswa yang belum mencapai KKM tersebut adalah siswa yang berkebutuhan khusus. Secara keseluruhan model Snowball Throwing terbukti dapat meningkatkan hasil belajar dengan kategori yang tinggi, yang pada kondisi awal rata-rata hasil belajar hanya 57,27 meningkat menjadi 80,45

\section{Pembahasan}

Hasil belajar siswa dalam materi daur hidup hewan dapat meningkat terjadi setelah siswa menggunakan model Snowball Throwing karena model Snowball Throwing ini dekat dengan dunia anak-anak yaitu permainan. Hal ini sesuai dengan teori dari beberapa penelitian. Rendahnya budaya motivasi dan hasil belajar siswa kelas IVC MIN 1 Rembang disebabkan karena kurangnya pemberian motivasi terhadap siswa, model pembelajaran yang kurang tepat, kurangnya latihan dalam mengerjakan soal-soal, kurangnya penggunaan media.

Dengan menerapkan model snwoball drawing ternyata dapat meningkatkan hasil belajar siswa kelas IV C MIN 1 Rembang tahun 2019, hal ini terbukti dengan hasil belajar meningkat dari ratarata kelas 57,27 menjadi 80,45.

Dalam penelitian ini model Snowball Throwing mampu memberikan hasil yang sangat signifikan dalam upaya meningkatkan hasil belajar siswa kelas IVC MIN 1 Rembang. Hal ini terbukti dari data pengamatan berupa hasil Kuantitatif.

Hasil kuantitatif merupakan hasil observer yang berupa nilai hasil belajar siswa kelas IVC MIN 1 Rembang. Hasil ini diperoleh dari skor beberapa poin yang dihitung dengan rumus pada lampiran mulai dari pra siklus, siklus I, dan siklus II, sehingga akan memunculkan nilai akhir dari KD yang dipelajari siswa kelas IVC
MIN 1 Rembang. Dari hasil pengamatan observer diperoleh hasil bahwa hasil belajar pada siswa kelas IVC MIN 1 Rembang mengalami peningkatan yaitu hasil belajar siswa dari nilai rata-rata kelas 57,27 meningkat menjadi 80,45.

\section{PENUTUP}

\section{Simpulan}

Berdasarkan hasil analisis data dan pembahasan yang telah dikemukakan sebelumnya, maka peneliti mengambil kesimpulan bahwa: Model pembelajaran Snwoball throwing dapat membantu meningkatkan hasil belajar siswa kelas IV C MIN1 Rembang tahun 2019. Hal tersebut dibuktikan dengan meningkatnya rata-rata hasil belajar siswa sebelum penggunaan teknik itu adalah 57,27 menjadi 69,09 pada siklus I dan 80,45 pada siklus II.

\section{Saran}

Berdasarkan hasil penelitian tersebut, penulis menyarankan kepada semua guru untuk selalu menggali segala potensi yang ada pada diri siswa dan guru sendiri untuk menciptakan berbagai inovasi pembelajaran untuk kemajuan siswa dan meningkat profesionalitas kerja. Sudah saatnya para guru untuk menumbuhkan budaya kreatif untuk merancang berbagai inovasi dalam pembelajaran. Oleh karena itu, hal yang perlu dilakukan adalah mengurangi kebiasaan hanya menjadikan buku teks sebagai satusatunya sumber belajar. Karena gurulah yang paling memahami kemampuan siswa, bagi peserta didik, hendaknya memperhatikan intruksi peneliti dalam pelaksanaan model pembelajaran snhowball throwing sehingga ketika dipraktekkan model pembelajaran tersebut tidak kebingungan dalam mempraktekkannya, dan bagi Madrasah hendaknya memberi dukungan kepada para peneliti supaya bisa memperlancar jalannya penelitian. 


\section{DAFTAR PUSTAKA}

Chukwuma, E.M., \& Obiefuna, O. (2014). Effect of Motivation on Employee Productivity : A Study of Manufacturing Companies in Nnewi. Journal of Managerial Studies and Research2 (7)

Dimyati dan Mujiono.2009. teori-teori belajar dan pembelajaran. Jakarta: Rineka Cipta

Hamalik (2015) Penilaian Autentik. Jakarta: Rajawali.

Jhon M. Echol dan Hasan sadhily. (1997). Kamus Inggris Indonesia, Jakarta: Gramedia

Juliah. (2013). Evaluasi Pembelajaran. Yogyakarta: Multi Pressido

M. Alisuf Sabri (2010). Psikologi Pendidikan, Jakarta: Pedoman Ilmu Jaya

Nana Sudjana dan Ibrohim (2009). Penelitian dan penilaian Pendidikan. Bandung:Sinar Baru Algesindo

Nana Sudjana (1982) . Penelitian Hasil Proses Pembelajaran. Bandung: Remaja Rosda Karya

Pamela, A.O., \& Oloko (2015). Effect of motivation on employee performance of commercial banks in kenya : A case study of Kenya Commercial Bank in Migori County. Journal of Human Resource Studies5

Pusdiklat Tenaga Teknis Pendidikan dan Keagamaan. (2018). Dokumen II Kurikulum Diklat Teknis Substantif Pendidikan. Jakarta: Pusdiklat Tenaga Teknis Pendidikan dan Keagamaan. 